\title{
PENGGUNAAN THINK-PAIR-SHARE UNTUK MENINGKATKAN KEAKTIFAN DAN PEMAHAMAN MEMBACA PESERTA DIDIK DALAM READING COMPREHENSION
}

\author{
Yadhi Nur Amin \\ MAN 2 Rembang \\ yadhialfaza66@gmail.com \\ DOI : http://doi.org/10.37730/edutrained.v4i2.66 \\ Diterima: 14 Juli 2020 | Disetujui: 26 November 2020 | Dipublikasikan: 29 November 2020

\begin{abstract}
Abstrak
Penelitian ini bertujuan untuk mengetahui keaktifan dan pemahaman membaca dalam reading comprehension. Subyek penelitiannya adalah peserta didik kelas XI MIPA-1 MAN 2 Rembang yang diajar dengan strategi Think-Pair-Share. Hasil yang diharapkan dalam penelitian ini adalah meningkatnya keaktifan dan pemahaman peserta didik, sehingga instrumen yang digunakan berupa lembar observasi untuk mengetahui keaktifan, dan tes untuk mengetahui pemahaman membaca peserta didik. Metode penelitiannya yaitu PTK yang terdiri empat tahapan (perencanaan, pelaksanaan, pengamatan, dan refleksi). Strategi pembelajaran dimulai dari Think, Pair, dan Share. Penelitian ini dilakukan dalam dua siklus. Hasil penelitian menunjukkan bahwa strategi Think-Pair-Share dapat meningkatkan keaktifan dan pemahaman membaca peserta didik. Analisis data keaktifan menunjukkan peningkatan yaitu kondisi awal 39,39\% (rendah), siklus pertama 79,29\% (sedang), dan siklus kedua $89,90 \%$ (tinggi). Selanjutnya, analisis data hasil tes pemahaman membaca juga menunjukkan peningkatan, yaitu kondisi awal 45,45\% (rendah), siklus pertama 66,67\% (sedang), dan siklus kedua 87,88\% (tinggi). Dengan demikian, strategi ini dianggap berhasil karena persentase ketuntasan sebesar $87,88 \%$ melebihi kriteria keberhasilan $75 \%$.
\end{abstract}

Kata Kunci: Think-Pair-Share, keaktifan, pemahaman membaca

\begin{abstract}
This study aims to improve the students' activeness and comprehension in reading comprehension. The subjects are students of class XI MIPA-1 MAN 2 Rembang taught by Think-Pair-Share strategy. The expected output is the increase of students' activeness and comprehension, so the instrument used is observation sheet to find out the students' activeness, and a test to determine their comprehension. The method is CAR consisting of four stages (planning, implementation, observation, and reflection). This research was conducted in two cycles. The results showed that Think-Pair-Share strategy could increase the students' activeness and comprehension. The data analysis of activeness showed an increase from pre-cycle of 39.39\% (low), Cycle I 79.29\% (fair), to Cycle II 89.90\% (high). Furthermore, the result of comprehension showed an increase from pre-cycle $45.45 \%$ (low), Cycle I $66.67 \%$ (fair), to Cycle II 87.88\% (high). Thus, this strategy is considered successful because the final result exceeds the $75 \%$ success criteria.
\end{abstract}

Keywords: Think-Pair-Share, activeness, reading comprehension 


\section{PENDAHULUAN}

Membaca merupakan aktivitas penting dalam setiap bahasa. Membaca memungkinkan orang untuk mencari informasi dari berbagai teks, informasi tertulis atau cetak dari surat kabar, majalah, iklan, brosur, whatsapp, dan sebagainya. Menurut Djiwandono (1996, p. 62) membaca adalah kegiatan yang penting dan menjadi lebih penting di dunia modern ini, di mana perkembangan dalam setiap aspek kehidupan terjadi sangat cepat. Sebagai bagian dari keterampilan berbahasa, membaca memainkan peran penting untuk keberhasilan pembelajaran bahasa.

Kemampuan atau keterampilan memahami pesan dalam teks merupakan tujuan membaca dalam instruksi bahasa. Namun demikian, membaca dianggap sebagai keterampilan yang rumit. Memahami pesan teks memang tidaklah mudah, terutama dalam bahasa Inggris. Hal itu ditunjukkan dengan berbagai hasil tes membaca mereka yang masih berada di bawah target. Mereka sering mengalami masalah dalam memahami teks yang terkait dengan kosakata dan kalimat kompleks, atau bahkan teks secara keseluruhan. Seseorang yang gagal mengetahui makna dari bagian itu berarti belum membaca (Burn, 1996, p. 25).

Berdasarkan pengamatan penulis di MAN 2 Rembang para peserta didik hampir tidak dapat memahami teks bacaan bahkan dalam teks sederhana. Selanjutnya, hasil studi pendahuluan menunjukkan bahwa hanya sedikit peserta didik kelas XI MIPA-1 yang dapat membaca dan memahami teks bacaan secara efisien. Ketidakmampuan peserta didik dalam memahami teks bacaan dibuktikan dengan nilai rata-rata peserta didik dalam studi pendahuluan hanya 55 jauh di bawah KKM 65. Hasil tes tersebut menunjukkan bahwa banyak peserta didik masih mengalami kesulitan dalam memahami teks bacaan berbahasa Inggris. Hal ini karena dalam memahami teks, mereka harus memusatkan perhatian pada beberapa aspek sebagai berikut: (1) mengenali kata dan frasa dari makna yang serupa dan berlawanan, (2) mengidentifikasi informasi, (3) membedakan elemen atau fitur dalam konteks; analisis elemen dalam struktur dan hubungannya, (4) menafsirkan ideide kompleks, tindakan, peristiwa, dan hubungan, (5) menyimpulkan teks, menurunkan, dan memprediksi kelanjutan, (6) menyintesis, dan (7) mengevaluasi (Cohen, 1994, p. 225).

Sejalan dengan masalah tersebut, peneliti menemukan kebiasaan umum para guru dalam proses belajar mengajar yaitu bahwa guru hanya menggunakan strategi konvensional dimana guru mendominasi instruksi kelas.Dalam strategi ini, guru biasanya membaca teks terlebih dahulu, meminta peserta didik untuk mengulang, dan kemudian meminta beberapa peserta didik membaca teks dengan keras. Setelah itu guru dan peserta didik mendiskusikan beberapa kosakata baru yang sulit bagi para peserta didik. Kemudian guru memberikan beberapa pertanyaan untuk dijawab oleh peserta didik. Hasilnya, banyak peserta didik masih mengalami kesulitan dalam menjawab pertanyaan.

Berdasarkan permasalahan tersebut, peneliti bermaksud untuk mengatasi masalah pembelajaran pemahaman bacaan dengan membawa peserta didik keluar dari kegiatan monoton, kebosanan, suasana kelas individual, menujukegiatan yang lebih berpusat pada peserta didik, diantaranya dengan menggunakan pembelajaran kooperatif. Joubert (1997) menjelaskan pembelajaran kooperatif sebagai strategi pembelajaran terstruktur yang menekankan pembelajaran aktif melalui interaksi interpersonal, di mana peserta didik bertindak sebagai mitra dengan guru dan satu sama lain. Peran pemain dalam pembelajaran kooperatif adalah guru dan peserta didik.

Strategi pembelajaran kooperatif Think-Pair-Share dipilih dalam penelitian ini untuk meningkatkan keaktfan dan pemahaman membaca peserta didik. Think-Pair-Share adalah strategi yang digunakan untuk memberikan kesempatan pada peserta didik untuk "berpikir" tentang topik yang diberikan, 
dan memungkinkan mereka untuk merumuskan ide-ide individu dan berbagi ide-ide ini dengan peserta didik lain. Mempertimbangkan manfaat dari strategi Think-Pair-Share tersebut, peneliti tertarik untuk menerapkan strategi tersebut untuk meningkatkan keaktifan dan pemahaman membaca peserta didik Kelas XI MAN 2 Rembang dengan melakukan penelitian tindakan kelas yang berjudul "Penggunaan Think-Pair-Share untuk Meningkatkan Keaktifan dan Pemahaman Membaca Peserta didik dalam Reading Comprehension".

Rumusan masalah dari penelitan ini adalah: "Sejauh mana peningkatan keaktifan dan pemahaman peserta didik dalam pembelajaran Reading Comprehension dengan menggunakan Strategi Think-Pair-Share?" Sedangkan tujuan dari penelitian ini adalah untuk mengetahui peningkatan keaktifan dan pemahaman membaca peserta didik kelas XI MAN 2 Rembang dalam Reading Comprehension. Penelitian ini diharapkan dapat memfasilitasi peserta didik untuk memahami teks bacaan dengan mudah dan untuk meningkatkan keaktifan dan keterampilan membaca mereka.

\section{KAJIAN PUSTAKA}

\section{Keaktifan Belajar}

Keaktifan pada proses belajar berarti suatu kegiatan individu yang dapat membawa perubahan kearah yang lebih baik pada diri invidu itu sendiri karena adanya interaksi antara individu satu dengan individu lain dan individu dengan lingkungannya. Djamarah (1994, p. 41) menyatakan bahwa tidak ada proses belajar tanpa keaktifan anak didik yang belajar. Anak didik pasti aktif dalam belajar, hanya kadar/bobot keaktifannya yang berbeda. Ada keaktifan belajar itu dengan kategori rendah, sedang, dan tinggi. Sifat dari keaktifan tersebut sangatlah dinamis sehingga seringkali mengalami perubahan, terkadang up (naik), dan down (turun). Perubahanperubahan tersebut dipengaruhi dari beberapa faktor antara lain faktor dari peserta didik dan guru sendiri. Karena guru berinteraksi secara langsung dengan peserta didik, maka diperlukan upayaupaya guru dalam membangkitkan semangat dan keaktifan peserta didik diantaranya melalui motivasi, media, metode serta strategi- strategi pembelajaran yang dapat memicu keaktifan peserta didik.

\section{Pemahaman Membaca}

Braunger dan Lewis (2001, p. 3) mengatakan membaca adalah proses yang kompleks, interaktif, menggunakan keterampilan dasar dan strategi lanjutan untuk memahami makna. Jelaslah bahwa dalam kegiatan membaca, kita melakukan komunikasi dengan penulis dengan mengaktifkan pengetahuan sebelumnya dan memparafrasakan atau menarik kesimpulan ide-ide penulis ke dalam pikiran kita sehingga akan membantu kita memahami apa yang penulis maksudkan. Dengan demikian membaca melibatkan pengembangan pemahaman teks, pemikiran tentang teks dengan cara yang berbeda, dan penggunaan berbagai jenis teks untuk tujuan yang berbeda. Lebih lanjut, pemahaman terjadi ketika pembaca membuat hubungan penting antara pengetahuan awal mereka dan pengetahuan baru yang ditemukan dalam teks. Saat membaca teks, pembaca mengaktifkan pengetahuan atau skemata sebelumnya tentang suatu topik. Pada titik akhir, pembaca dewasa yang mahir dapat membaca berbagai materi dengan mudah dan menarik, dapat membaca untuk berbagai tujuan, dan dapat membaca dengan pemahaman bahkan ketika materi tidak mudah dipahami atau secara intrinsik menarik (Braunger \& Lewis, 2001, p. 15).

\section{Strategi Think-Pair-Share (TPS)}

Arends(1997), berpendapat bahwa strategi Think-Pair-Share merupakan salah satu model pembelajaran kooperatif untuk memberikan lebih banyak waktu untuk berpikir kepada peserta didik secara individual dan menyiapkan tanggapan mereka sendiri terhadap masalah yang akan dibahas sebelum menuju ke langkah berikutnya, sekaligus 
mereka dapat saling membantu. Strategi Think-Pair-Share adalah teknik pembelajaran kooperatif yang mendorong partisipasi individu. Ini berlaku di semua tingkat kelas dan ukuran kelas. Selain itu, strategi ini juga dapat digunakan sebelum memperkenalkan konsep-konsep baru. Strategi ini juga memberi waktu kepada setiap peserta didik di kelas untuk mengakses pengetahuan sebelumnya dan memberikan kesempatan bagi mereka untuk berbagi ide dengan peserta didik lain.

Arends (1997) mengusulkan tiga langkah dalam strategi TPS, yaitu, berpikir, berpasangan, dan berbagi. Langkah pertama adalah berpikir. Dalam langkah ini, guru mengajukan pertanyaan atau masalah yang terkait dengan pelajaran dan meminta peserta didik untuk menggunakan waktu satu menit berpikir sendiri tentang jawaban atau masalah. Supaya bisa fokus berpikir, peserta didik perlu diajarkan bahwa berbicara atau berjalan bukanlah bagian dari waktu berpikir.

Langkah kedua yaitu berpasangan, dimana guru meminta peserta didik untuk berpasangan dan mendiskusikan apa yang telah mereka pikirkan. Interaksi selama periode ini dapat berupa berbagi jawaban jika sebuah pertanyaan diajukan atau berbagi ide jika masalah tertentu diidentifikasi. Biasanya, guru tidak akan mengizinkan lebih dari 4 atau 5 menit untuk berpasangan.

Langkah terakhir adalah berbagi, yaitu guru meminta pasangan untuk berbagi dengan seluruh kelas tentang apa yang telah mereka bicarakan. Sangat efektif berkeliling ruangan dari pasangan ke pasangan dan terus sampai sekitar seperempat atau setengah dari pasangan yang memiliki kesempatan untuk melaporkan.

Prosedur atau langkah-langkah untuk menjalankan strategi Think-Pair-Share dapat disimpulkan sebagai berikut: (1) guru mengajukan masalah atau menanyakan pertanyaan terbuka yang mungkin ada berbagai jawaban; (2) guru memberi peserta didik 'waktu berpikir' dan mengarahkan mereka untuk memikirkan pertanyaan, kemudian mengikuti peserta didik untuk menghadapi mitra belajar mereka dan bekerja bersama, berbagi ide, berdiskusi, dan mengklarifikasi; dan (3) setiap pasangan berbagi ide dengan pasangan lain, atau dengan seluruh kelas. Penting diberitahukan bahwa peserta didik harus dapat berbagi ide-ide pasangan mereka serta ide mereka sendiri.

Strategi Think-Pair-Share pernah digunakan oleh Saparudin (2004) pada SMP Negeri 6 Malang dan Pattiiha (2006) pada SD Negeri Sumbersari yang terbukti dapat meningkatkan pemahaman membaca peserta didik.

\section{METODE PENELITIAN}

Metode penelitian ini adalah Penelitian Tindakan Kelas (PTK) yang terdiri dari 4 (empat) tahapan. Prosedur penelitian tindakan ini dimulai dari merencanakan tindakan, melaksanakan, mengamati selama pelaksanaan, dan merefleksikan, yang sebelumnya didahului dengan studi pendahuluan. Penelitian ini dilakukan di MAN 2 Rembang dengan mengambil subyek peserta didik Kelas XI MIPA-1 Semester Genap Tahun Pelajaran 2019/2020, berjumlah 33 peserta didik yang terdiri dari 8 laki-laki dan 25 perempuan. Dalam pelaksanaan PTK ini, peneliti dibantu oleh teman sejawat, dimana peneliti sebagai pengajar dan teman sejawat sebagai pengamat selama proses pembelajaran.

Penelitian ini menggunakan instrumen dalam pengumpulan data yang meliputi lembar observasi dan tes untuk mengolah data hasil penelitian. Lembar observasi diisi oleh teman sejawat berupa pengamatan segala kegiatan yang dilakukan oleh peneliti maupun peserta didik, baik dengan cara mencatat, membuat daftar atau mencentang indkator yang sudah disiapkan. Sedangkan instrumen tes digunakan untuk memperoleh data hasil belajar peserta didik terkait dengan pemahaman membaca (reading comprehension) berupa tes tulis dengan bentuk soal pilihan ganda dan uraian singkat. Tes 
diberikan pada pertemuan ke-3 dalam setiap siklus.

Analisis data dilakukan setelah pelaksanaan tindakan dan pengamatan pembelajaran pada setiap siklus. Data yang dianalisis pada penelitian ini berasal dari instrumen yang digunakan yaitu lembar observasi dan nilai tes. Analisis data menggunakan teknik deskriptif analitik, yang tahap-tahapnya meliputi reduksi data, menyajikan data dan membuat abstraksi atas kesimpulan makna hasil analisis (verifikasi atau penarikan kesimpulan). Teknik deskriptif analitik dilakukan dengan cara mengumpulkan data yang terdiri dari data-data kuantitatif yang diperoleh dari nilai hasil tes yang diolah dengan menggunakan deskripsi persentase dan data kualitatif yang diperoleh dari lembar obseravasi terkait kegiatan peneliti dan kegiatan peserta didik dalam proses pembelajaran yang dijadikan dasar dalam penentuan keaktifan peserta didik dalam mengikuti proses pembelajaran dengan strategi Think-Pair-Share.

Penelitian ini dilaksanakan pada pertengahan Februari sampai akhir Maret 2019, dengan indikator keberhasilan antara lain: (1) skor keaktifan peserta didik mencapai minimal $60 \%$ dari keseluruhan peserta didik dan masuk kategori tinggi, yaitu 81 - 100, dan (2) $75 \%$ peserta didik mencapai skor minimal 65 dalam tes reading comprehension.

\section{HASIL PENELITIAN DAN PEMBAHASAN}

\section{Hasil Penelitian}

Berdasarkan pengamatan dari 3 (tiga) observer pada siklus 1 terkait dengan keaktifan peserta didik ditemukan hal-hal sebagai berikut: (1) Observer 1 menemukan bahwa persentase peserta didik yang memiliki keaktifan rendah ada $19,70 \%$, kategori sedang ada $50 \%$, dan kategori tinggi ada 30,30\%; (2) Observer 2 menyimpulkan bahwa persentase peserta didik yang memiliki keaktifan rendah ada $24,24 \%$, kategori sedang ada $48,48 \%$, dan kategori tinggi ada $27,27 \%$; dan (3) Observer 3 mendapatkan persentase peserta didik yang memiliki keaktifan rendah ada 18,18\%, kategori sedang ada 50,09\%, dan kategori tinggi ada $22,73 \%$. Dari hasil pengamatan ketiga observer tersebut, persentase rata-rata yang diperoleh adalah: (1) Rendah sebesar 20,71\%; (2) Sedang sebesar 52,52\%; dan (3) Tinggi sebesar 26,77\%. Ketika dijumlahkan kategori Sedang dan Tinggi diperoleh hasil 79,29\% sehingga keaktifan dikategorikan sedang. Hal ini menunjukkan bahwa secara umum keaktifan peserta didik selama mengikuti pembelajaran reading comprehension dengan strategi Think-Pair-Share tergolong baik. Namun demikian, persentase $79,29 \%$ masih dalam kategori sedang, sehingga persentase tersebut belum mencapai kriteria ketuntasan dengan kategori tinggi (81 - 100). Berikutnya, hasil perhitungan setiap indikator aktivitas peserta didik menunjukkan bahwa persentase rata-rata perolehan skor indikator aktivitas peserta didik pada siklus 1 hanya 52,02\%. Ratarata tersebut diperoleh dari observer 1 sebesar 52,27\%, observer 2 sebesar $51,52 \%$, dan observer 3 sebesar 52,27\%. Dengan demikian, secara detail indikator keberhasilan untuk keaktifan peserta didik sebesar $60 \%$ belum tercapai karena masih kurang 7,98\%. Oleh karena itu, perlu dilakukan perbaikan-perbaikan untuk melanjutkan penelitian ke siklus berikutnya, yaitu siklus 2 .

Terkait dengan pemahaman peserta didik, data yang diperoleh dari hasil nilai tes Reading Comprehension menunjukkan bahwa rata-rata nilai yang diperoleh sebesar 67,82 dan peserta didik tuntas sama dengan KKM sejumlah 12 peserta didik $(36,37 \%)$, lebih dari KKM sejumlah 10 peserta didik $(30,30)$ dan peserta didik tidak tuntas berjumlah 11 orang $(33,33 \%)$. Dilihat dari data tersebut, peserta didik yang sudah tuntas $(\geq \mathrm{KKM})$ sejumlah 22 atau $66,77 \%$, meningkat $21,22 \%$ dari kondisi awal (45,45\%), namun belum mencapai indikator keberhasilan sebesar $75 \%$ peserta didik tuntas (masih kurang 8,33\%).

Setelah mengkaji proses pembelajaran yang dilakukan pada siklus 
pertama terkait keaktifan peserta didik dan hasil belajar peserta didik, peneliti melakukan refleksi terhadap pembelajaran yang telah dilakukan dalam 3 (tiga) pertemuan. Kegiatan ini dibantu oleh teman sejawat yang sekaligus observer, yang terlibat langsung dalam proses pembelajaran sehingga mengetahui kelemahan dan kelebihan dalam proses pembelajaran, yang selanjutnya menetapkan langkah-langkah perbaikan untuk dilaksanakan pada siklus kedua. Secara umum langkah-langkah pembelajaran pada siklus 2 ini sama dengan pada siklus 1 . Perbedaannya adalah pada tindakan pada setiap langkah dioptimalkan sesuai hasil refleksi pada siklus 1 .

Berdasarkan pengamatan dari 3 (tiga) observer terkait dengan keaktifan peserta didik ditemukan hal-hal sebagai berikut: (1) Observer 1 menemukan bahwa persentase peserta didik yang memiliki keaktifan rendah ada 7,58\%, kategori sedang ada 40,91\%, dan kategori tinggi ada 51,51\%; (2) Observer 2 menyimpulkan bahwa persentase peserta didik yang memiliki keaktifan rendah ada $10,61 \%$, kategori sedang ada $39,39 \%$, dan kategori tinggi ada 50,00\%; dan (3) Observer 3 mendapatkan persentase peserta didik yang memiliki keaktifan rendah ada $12,12 \%$, kategori sedang ada $30,30 \%$, dan kategori tinggi ada 57,58\%. Dari hasil pengamatan ketiga observer tersebut, persentase rata-rata yang diperoleh adalah: (1) Rendah sebesar 10,10\%; (2) Sedang sebesar 36,87\%; dan (3) Tinggi sebesar 53,03\%. Ketika dijumlahkan kategori Sedang dan Tinggi diperoleh hasil 89,90\% sehingga keaktifan dikategorikan tinggi. Hal ini menunjukkan bahwa secara umum keaktifan peserta didik selama mengikuti pembelajaran reading comprehension dengan strategi Think-Pair-Share tergolong tinggi. Disamping itu, terjadi peningkatan keaktifan peserta didik pada siklus 2 dimana kategori tinggi naik sebesar 26,26\% (dari siklus 1 sebesar $26,27 \%$ menjadi 53,03\%) meskipun kategori sedang turun $15,65 \%$ (dari siklus 1 sebesar 52,52\% menjadi $36,87 \%$ ), dan kategori rendah yang menunjukkan peserta didik tidak aktif turun 10,61\%. Selanjutnya, persentase kategori sedang dan tinggi berjumlah 89,90\% yang berarti naik 10,61\% (dari siklus 1 sebesar $79,29 \%$ menjadi $89,90 \%$ ), sehingga menunjukkan bahwa secara umum peserta didik aktif dalam pembelajaran. Hal tersebut menunjukkan bahwa keaktifan peserta didik dari siklus 1 ke siklus 2 mengalami peningkatan yang sangat bagus. Kemudian, terkait dengan indikator keberhasilan yang harus tercapai kategori tinggi juga telah terpenuhi, yaitu persentase $89,90 \%$ termasuk dalam kategori tinggi (81 $100)$, sehingga persentase tersebut sudah mencapai kriteria keberhasilan. Hal ini berarti bahwa tindakan yang dilakukan dengan menggunakan strategi Think-PairShare dapat meningkatkan keaktifan belajar peserta didik.

Peningkatan juga ditunjukkan dari hasil perhitungan setiap indikator aktivitas peserta didik dimana persentase rata-rata perolehan skor pada siklus 2 sudah sebesar $68,26 \%$. Rata-rata tersebut diperoleh dari rata-rata observer 1 sebesar 68,06\%, observer 2 sebesar $67,80 \%$, dan observer 3 sebesar 68,94\%. Dengan demikian, indikator keberhasilan untuk keaktifan peserta didik sebesar $60 \%$ sudah tercapai, yaitu $68,26 \%$ lebih besar daripada $60 \%(68.26 \%>60 \%)$. Oleh karena itu, penelitian yang berkaitan dengan keaktifan dianggap berhasil dan selesai, yang berarti strategi Think-PairShare dapat meningkatkan keaktifan peserta didik dalam pembelajaran reading comprehension.

Terkait dengan pemahaman membaca peserta didik, Data yang diperoleh dari hasil nilai tes Reading Comprehension menunjukkan bahwa rata-rata nilai sebesar 78,70 dan peserta didik tuntas sama dengan KKM sejumlah 0 peserta didik $(0 \%)$, lebih dari KKM sejumlah 29 orang $(87,88)$ dan peserta didik tidak tuntas berjumlah 4 orang $(12,12 \%)$. Dilihat dari data tersebut, diketahui bahwa peserta didik yang sudah tuntas ( $\geq$ KKM) sejumlah 29 atau $87,88 \%$. Dilihat dari persentase ketuntasan sebesar 
$87,88 \%$ sedangkan indikator keberhasilan yaitu 75\%, maka pembelajaran ini dianggap berhasil, dimana hasil pembelajaran lebih besar daripada indikator keberhasilan $(87,88 \%$ $>$ 75\%). Dengan demikian, penelitian terkait hasil pemahaman membaca peserta didik dianggap sudah berhasil dan selesai.

\section{Pembahasan}

Keaktifan dan hasil pemahaman membaca peserta didik sangat ditentukan oleh proses pembelajaran yang dilakukan oleh guru dan peserta didik. Proses pembelajaran yang monoton dan membosankan akan mengakibatkan keaktifan dan hasil belajar peserta didik rendah. Oleh karena itu, diperlukan strategi tertentu dan variatif untuk meningkatkan keaktifan dan hasil pemahaman membaca peserta didik. Salah satu strategi tersebut adalah ThinkPair-Share (TPS), dimana strategi tersebut memberikan kesempatan yang lebih kepada peserta didik untuk terlibat aktif dalam proses pembelajaran.

Dengan berbagai kelebihan dan kekurangan yang kemudian diperbaiki bersama dengan observer, keaktifan peserta didik pada setiap pertemuan dapat meningkat. Untuk selanjutnya, guru (peneliti) harus lebih memperhatikan halhal berikut: (1) pemberian motivasi kepada peserta didik lebih ditingkatkan, (2) pemberian stimulus dan kesempatan kepada peserta didik untuk menyampaikan pendapat, dalam hal ini berdiskusi dan menyampaikan hasil diskusi, dan (3) dominasi guru dalam proses pembelajaran perlu dikurangi.

Hasil analisis data keaktifan peserta didik menunjukkan peningkatan yang baik dari kondisi awal, siklus 1 dan siklus 2. Peningkatan keaktifan peserta didik pada siklus 2 yang masuk kategori tinggi naik sebesar 26,26\% (dari siklus 1 sebesar 26,27\% menjadi 53,03\%) dan kategori rendah yang menunjukkan peserta didik tidak aktif turun 10,61\%. Kemudian, ketika dijumlahkan persentase kategori sedang dan tinggi terdapat hasil $89,90 \%$, yang berarti naik 10,61\% (dari siklus 1 sebesar $79,29 \%$ menjadi 89,90\%). Hal ini menunjukkan bahwa secara umum peserta didik aktif dalam pembelajaran. Bahkan jika dibandingkan dengan kondisi awal yang hanya 39,39\%, maka terjadi kenaikan sebesar 50,51\% $(39,39 \%$ naik menjadi $89.90 \%)$ yang menunjukkan separo lebih kenaikannya. Kemudian, terkait dengan indikator keberhasilan yang harus mencapai kategori tinggi juga telah terpenuhi, yaitu persentase $89,90 \%$ termasuk dalam kategori tinggi (81 - 100), sehingga persentase tersebut sudah mencapai kriteria keberhasilan. Ini berarti bahwa tindakan yang dilakukan dengan menggunakan strategi Think-Pair-Share dapat meningkatkan keaktifan belajar peserta didik. Untuk lebih jelas dapat dilihat pada tabel dan grafik berikut ini.

Tabel 1. Hasil Keaktifan Peserta didik pada Kondisi Awal, Siklus 1 dan 2

\begin{tabular}{cccc}
\hline \multirow{2}{*}{ Kategori } & \multicolumn{3}{c}{ Keaktifan Peserta didik } \\
& \multicolumn{3}{c}{$\mathbf{( \% )}$} \\
\cline { 2 - 4 } & $\begin{array}{c}\text { Kondisi } \\
\text { Awal }\end{array}$ & $\begin{array}{c}\text { Siklus } \\
\mathbf{1}\end{array}$ & $\begin{array}{c}\text { Siklus } \\
\mathbf{2}\end{array}$ \\
\hline Tinggi & 15,15 & 26,77 & 53,03 \\
\hline Sedang & 24,24 & 52,52 & 36,87 \\
\hline Rendah & 60,61 & 20,71 & 10,10 \\
\hline Ketuntasan & 39,39 & $\mathbf{7 9 , 2 9}$ & $\mathbf{8 9 , 9 0}$ \\
\hline
\end{tabular}

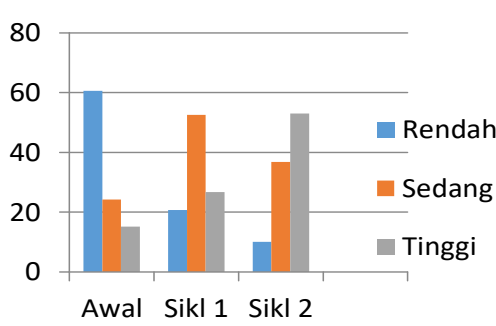

Selanjutnya, analisis data hasil pemahaman membaca peserta didik menunjukkan bahwa adanya peningkatan yang baik dari kondisi awal, ke siklus 1 dan siklus 2. Mengacu pada indikator keberhasilan sebesar $75 \%$ peserta didik tuntas, maka pembelajaran ini dianggap berhasil karena persentase ketuntasan 
yang diperoleh sebesar 87,88\% yang menunjukkan hasil pembelajaran lebih besar daripada indikator keberhasilan $(87,88 \%>75 \%)$. Hasil pemahaman membaca peserta didik pada kondisi awal, siklus pertama dan siklus kedua dapat dilihat pada pada tabel dan grafik berikut ini.

Tabel 2. Hasil Pemahaman Membaca pada Kondisi Awal, SIklus 1 dan Siklus 2

\begin{tabular}{|c|c|c|c|}
\hline \multirow[b]{2}{*}{ Kategori } & \multicolumn{3}{|c|}{ Nilai Pemahaman (\%) } \\
\hline & $\begin{array}{c}\text { Kondis } \\
\text { i Awal }\end{array}$ & $\begin{array}{c}\text { Siklus } \\
1\end{array}$ & $\begin{array}{c}\text { Siklus } \\
2\end{array}$ \\
\hline $\begin{array}{c}\text { Belum } \\
\text { Tuntas (BT) }\end{array}$ & 54,54 & 33,33 & 12,12 \\
\hline Tuntas (ST) & 45,45 & 66,67 & 87,88 \\
\hline $100,00 \%$ & & & \\
\hline $80,00 \%$ & & & \\
\hline $60,00 \%$ & & & BT \\
\hline $40,00 \%$ & & & ST \\
\hline $20,00 \%$ & & & \\
\hline $0,00 \%$ & & & \\
\hline
\end{tabular}

Gambar2. Hasil Pemahaman Membaca pada Kondisi Awal, SIklus 1 dan Siklus 2

\section{PENUTUP}

\section{Simpulan}

Penggunaan strategi Think-Pair-Share (TPS) dapat digunakan dalam pembelajaran reading comprehension sesuai dengan teori-teori yang dijelaskan pada kajian pustaka.
Berdasarkan hasil penelitian dan tujuan penelitian untuk mengetahui peningkatan keaktifan dan pemahaman membaca peserta didik dalam Reading Comprehension, dapat disimpulkan bahwa: (1) Hasil penelitian ini menunjukkan bahwa strategi Think-PairShare dapat meningkatkan keaktifan peserta didik dalam pembelajaran reading comprehension. Hal ini ditunjukkan dengan peningkatan keaktifan peserta didik dari kondisi awal 39,39\% termasuk kategori rendah, siklus pertama 79,29\% termasuk kategori sedang, dan siklus kedua $89,90 \%$ termasuk kategori tinggi; dan (2) strategi Think-Pair-Share berhasil meningkatkan hasil pemahaman membaca peserta didik. Hasil penelitian menunjukkan bahwa adanya peningkatan persentase ketuntasan dari kondisi awal $45,45 \%$ termasuk rendah, siklus pertama $66,67 \%$ termasuk sedang, dan siklus kedua $87,88 \%$ termasuk tinggi.

\section{Saran}

Dari hasil penelitian yang diperoleh, beberapa saran disampaikan untuk meningkatkan proses pembelajaran yang lebih baik sebagai berikut: (1) Guru dapat melaksanakan pembelajaran reading comprehension dengan strategi ThinkPair-Share, namun guru harus melakukan perencanaan yang matang terkait dengan pemberian motivasi, stimulus dan kesempatan lebih besar kepada peserta didik untuk lebih aktif; (2) guru hendaknya lebih sering melatih peserta didik dengan berbagai metode pembelajaran untuk meningkatkan keterampilan, keaktifan, dan prestasi belajar peserta didik, dan (3) peneliti selanjutnya dapat melakukan penelitian dengan metode yang lain maupun menggunakan strategi Think-Pair-Share dalam bidang ilmu, materi atau keterampilan lainnya. 


\section{DAFTAR PUSTAKA}

Arends, R. (1997). Introduction to Classroom Instruction and Management. New York: McGraw-Hill Company, Inc.

Arikunto, Suharsimi. (1998). Prosedur Penelitian: Suatu Pendekatan Praktik. Jakarta: PT. Rineka Cipta.

Braunger \& Lewis. (2001). Building Knowledge Base in Reading, 2nd Edition. Delaware: International Reading Association and the National Councils of Teachers of English.

Burn, et.al. (1996). Teaching Reading in Today's Elementary School. In e. Burn, Teaching Reading in Today's Elementary School (p. 25). Boston: Houghtoun Mifflin Comp.

Cohen, D. (1994). Assessing Language Ability in the Classroom. In D. Cohen, Assessing Language Ability in the Classroom (p. 225). USA: Heinle \& Heinle Publisher.

Djamarah, S. B. (1994). Prestasi dan Kompetensi Guru. Surabaya: Usaha Nasional.

Djiwandono, M. (1996). Tes Bahasa dalam Pengajaran. In M. Djiwandono, Tes Bahasa dalam Pengajaran (p. 62). Bandung: Penerbit ITB.

Joubert, T. (1997, April 14). Roles and Social Interaction. Roles and Social Interaction. , p. 18.

Kemmis, Stephen, McTaggart, Robin. (1988). The Action Research Planner. Australia: Deakin University Press.

Lewis, J. B. (2001). Building Knowledge Base in Reading, 2nd Edition. Delaware: International Reading Association and the National Councils of Teachers of English.

Mulyasa, E. (2010). Penelitian Tindakan Sekolah. Bandung: Remaja Rosdakarya.

Pattiiha. (2006). Improving the Implementation of the Learning of Beginning Reading among Second Year Students at SDN Sumbersari by Using the Think-Pair-Share Strategy. Malang: Universitas Negeri Malang.

Saparudin. (2004). Improving Reading Comprehension Achievement of the Third Year Students of SLTPN 6 Malang by Using Think-Pir-Share-Square (TPPS) Strategy. Malang: Universitas Negeri Malang.

Wiraatmaja, Rochiati. (2009). Metode Penelitian Tindakan Kelas. Bandung: Rosdakarya. 